\title{
The Effect of Science Digital Scrapbook Based on the Universal Design for Learning (UDL) on Students'
}

\author{
Indah Urwatin Wusqo ${ }^{1,2,} *$, Niken Ayu Lestari Bondan Jatiningsih ${ }^{2}$, Supinah $^{3}$ \\ ${ }^{1}$ Educational Research and Evaluation Study Program, Universitas Negeri Yogyakarta, Indonesia \\ ${ }^{1,2}$ Science Education Study Program, Integrated Sciences Department, Universitas Negeri Semarang, Indonesia \\ ${ }^{3}$ SMP Negeri 24 Semarang, Indonesia \\ * Corresponding author. Email: urwatin@mail.unnes.ac.id
}

\begin{abstract}
The students' learning outcomes in the COVID-19 pandemic era were declining. Science learning resources are often not suitable for online teaching and learning. The Science Digital Scrapbook has been developed based on the Universal Design for Learning (UDL) to support science teaching and learning. This study aimed to examine the effect of the Science Digital Scrapbook based on UDL on the students' learning outcomes. This study was quasiexperiment research that utilized a post-test-only control-group design. The participants were students in Class VIII C and VIII D at SMP N 24 in Semarang. Students' social cognitive learning outcomes were assessed using a test. The Mann-Whitney U was used to compare the post-test between the two groups. The results indicated that the students' cognitive learning outcomes were higher in the experiment group compared to the control group. It is concluded that the Science Digital Scrapbook is an effective learning resource to improve students' learning outcomes.
\end{abstract}

Keywords: learning outcome, scrapbook, science digital universal design for learning

\section{INTRODUCTION}

The COVID-19 pandemic has impacted all life sectors, and the education field is no exception [1]. One of the policies taken in the education field is the implementation of learning from home for students, starting from elementary to university level [2]. The problem of teaching during the COVID-19 pandemic has become a serious problem throughout the world, including in Indonesia. Learning from home can be done either online or offline. Most of what is done in Indonesia is carried out online, especially for students living in internet-accessible areas. This online learning utilizes internet media and other supporting technologies [3].

Online learning is carried out by utilizing technology and communication for the continuity of the teaching and learning process during the pandemic period [4]. Online learning is defined as a transfer of knowledge that was conducted using internet network support, video, audio, images, text communication, and software
[5]. Online learning requires educators and students to maintain the interaction between them in the transfer of knowledge. Online learning utilizes various platforms, such as applications, websites, social networks, and also learning management systems. These various platforms are beneficial to support knowledge transfer, that are supported by various discussion techniques and other features [6].

Several obstacles have emerged as a result of changed learning methods which include (1) teachers' lack of knowledge to vary educational media; (2) teachers focusing on providing learning modules, (3) learning discrepancy with the lesson plan, and (4) teacher-centered learning [7]. On the other hand, learning activities during the Covid-19 pandemic should be interesting to students and avoid monotonous activities. Teachers must also provide quality learning facilities that stimulate critical, creative, and productive thinking skills as well as develop life skills. Therefore, it is essential to develop attractive and varied digital 
teaching materials to stimulate students' learning motivation [8].

Science learning is not only about aspects of knowledge but also a procedural aspect. One of the topics in science learning that is considered very complicated is the digestive system [9]. Students are required to know food as a source of nutrition, the organs that make up the digestive system, and their functions, as well as diseases and efforts to maintain the organs' health. This topic consists of many submaterials that must be conveyed through visual media, where students must know the shape of the organs that make up the digestive system and their functions. Teachers were aware that their lack of understanding about the online learning media could result in students' inability to comprehend the materials. Therefore, the use of learning media on the materials needs to be optimized. Moreover, adequate teaching materials are needed to facilitate students to carry out independent learning accompanied by simple practicum activities. Similar activities to prove the various kinds of nutrients needed by the human body at home by using daily chemical materials have been reported previously in a study [10].

To provide alternative learning material, a science digital scrapbook based on Universal Design for Learning (UDL) according to the 2013 Curriculum has been developed [11]. The Science Digital Scrapbook is a digital interactive teaching media containing Digestive System materials for the odd semester of Grade VIII. It adopts the concept of UDL, which emphasizes learning for all student profiles in inclusive classes by following three principles; representation, action and expression, and engagement. This UDL principle is considered because all schools in Semarang are inclusive thus also cater to special needs students.

Based on the characteristics of the preparation of online teaching materials [12], the UDL-based Science Digital Scrapbook is suitable for use as teaching material for online learning because (1) it is made in digital format, (2) it covers a large topic that needs to be divided into sub-topics, (3) the documents are in HTML, txt, doc, pdf, ppt, Xls, jpg, SWF, zip, mp3, MPEG, MOV, WMV, etc.; and (4) it corresponds the suggested file size (5 MB max). These files need to be organized so that they are easy to find and use in preparation for e-learning implementation, whether using LMS, authoring tools, or another web programming. This study was aimed at evaluating the effect of the UDL-based Digital Science Scrapbook on student learning outcomes at SMP Negeri 24 Semarang, Indonesia.

\section{MATERIAL \& METHODOLOGY}

The research, which was conducted at SMP 24 Semarang, was quasi-experimental. The design adopted a post-test-only intervention and control design (experimental and control classes). The research subjects were grade VIII $\mathrm{C}$ as the experimental class and VIII D as the control class consisting of 25 students each. The sample was determined using a cluster random sampling technique.

Data were collected through tests in the form of multiple-choice comprising 30 test items. Before constructing the test items, a test grid was developed according to the digestive system materials with varying cognitive levels ranging from $\mathrm{C} 1$ to $\mathrm{C} 6$ levels to describe the cognitive learning outcomes. The developed test items were then undergone validity and reliability assessments. The results showed that they were valid and reliable to use as research instruments to measure students' cognitive learning outcomes on the digestive system topic.

The data obtained were firstly analyzed using descriptive statistics. Statistical calculations were conducted to determine the mean, median, mode, and standard deviation scores. The statistical calculations included (1) analysis of prerequisite test consisting of normality and homogeneity test, and (2) hypothesis test, carried out by considering the analysis prerequisite test If the data were normally distributed, an independent $\mathrm{t}$ test should be used, and if the data were not normally distributed, the Mann-Whitney U test would be used.

\section{RESULTS AND DISCUSSION}

This study studied the student learning outcomes after using the developed scrapbook in VIII grade students of SMP N 24 Semarang. The student's understanding of the materials could be derived from the learning outcomes, which referred to the scores of students' test results before and after doing the learning activities. Two essential and interrelated aspects of learning are the selection of media and learning methods. The comparison of the two classes' average learning outcomes is presented in the following Table:

Table 1. Descriptive Statistics

\begin{tabular}{|l|c|c|}
\hline Criteria & $\begin{array}{l}\text { Experimental Class } \\
\text { (UDL-based Science } \\
\text { Digital Scrapbook) }\end{array}$ & $\begin{array}{l}\text { Control Class } \\
\text { (Science } \\
\text { Textbook) }\end{array}$ \\
\hline Mean & 82.9200 & 69.64 \\
\hline Max Score & 100 & 97 \\
\hline Min Score & 50 & 37 \\
\hline
\end{tabular}

Table 1 shows that the experimental class's highest score was 100 , and the lowest was 50 , with an average 
of 82.92. On the other hand, the control class's highest score was 97, and the lowest was 37, with 69.64. Descriptively, the average score of the experimental course was higher than the control class.

Table 2. Normality test

\begin{tabular}{|c|c|c|c|c|}
\hline & \multirow[t]{2}{*}{ Class } & \multicolumn{3}{|c|}{ Kolmogorov-Smirnova } \\
\hline & & Statistic & df & Sig. \\
\hline \multirow[t]{2}{*}{$\begin{array}{l}\text { Learning } \\
\text { outcom } \\
\text { es }\end{array}$} & $\begin{array}{l}\text { Experimental Class } \\
\text { (UDL-based Science } \\
\text { Digital Scrapbook) }\end{array}$ & .128 & 25 & .200 \\
\hline & $\begin{array}{l}\text { Control Class (Science } \\
\text { Textbook) }\end{array}$ & .258 & 25 & .000 \\
\hline
\end{tabular}

The data are typically distributed when having a value bigger than 0.05 . Thus, based on Table 2 , the control class' sig. Value was $<0.05$, so that the data were not normally distributed. Consequently, further analysis shall use the non-parametric statistics of the Mann-Whitney U test. The basis of the Mann-Whitney test's proof is if H0 (Asymp. Sig.> 0.05) is accepted, then the UDL-based Science Digital Scrapbook does not affect student learning outcomes. If $\mathrm{H} 0$ is rejected, then the UDL-based Science Digital Scrapbook is declared to influence student learning outcomes. The description of the Mann-Whitney result analysis is presented in the following Table.

Table 3. Mann-Whitney U

\begin{tabular}{|l|l|}
\hline Statistic & Value \\
\hline Mann-Whitney U & 169.000 \\
\hline Wilcoxon W & 494.000 \\
\hline Z & -2.803 \\
\hline $\begin{array}{l}\text { Asymptotic. Sig. (2- } \\
\text { tailed) }\end{array}$ & .005 \\
\hline
\end{tabular}

Based on Table 3, the asymptotic value. Sig (2tailed) was 0.005 or smaller than 0.05 , indicating that the Ho hypothesis was rejected. Hence, it can be stated that the UDL-based Science Digital Scrapbook influenced the student learning outcomes. The effect size was analyzed with the criteria of under 0.5 as minor, between $0.50-0.80$ as moderate, and above 0.8 2.0 as large. The calculation results obtained that 1,573 were in the range of $0.8-2.0$. Therefore, they had a large or significant effect.

Based on the research results, teachers as facilitators must provide convenience in online learning activities in the form of media/digital teaching resources [13-14]. Science digital scrapbook based on UDL is a digital teaching material that can be accessed through students' gadgets and PCs. Based on the Mann Whitney U test and the effect size, it had a significant effect on student learning outcomes as it was designed following the 2013 curriculum, which covers both the cognitive domain of Basic Competencies 3.5, namely "analyzing" the digestive system in humans and understanding disorders related to the digestive system as well as efforts to maintain a healthy digestive system." In addition, it also facilitated learners to achieve Basic Competencies 4.5, namely "presenting the investigation results on mechanical and chemical digestion" [15].

Learning science using the activity steps contained in the UDL-based SDS helped the students acquire the concept of the digestive system. The topic is divided into several sub-topics, including nutrition, organs of the digestive system, and efforts to overcome diseases in the digestive system. The students carried out practical activities using daily chemicals based on the procedural videos provided in the media. Hence, though the practicum was performed independently, the students could do it well and safely, referring to the clear and standardized steps. They also gained experience from the independent investigation of mechanical and chemical digestive processes according to the Basic Competencies 4.5 , then presented the investigation results. This individual activity followed the UDL design principle, action, and expression, which is beneficial for them to construct their knowledge well [16]. Another manifestation of this principle was the provided practical instructions in videos, which made it convenient for the students to follow [17]. Referring to [18], if someone gains knowledge from an invention, then that person can improve the ability to find and solve problems. The students in the inclusive class were interested and enthusiastic in carrying out the practicum. The completeness evidenced this in submitting practicum reports.

The UDL-based Science Digital Scrapbook contains minimalistic pictures and descriptions, which becomes one of the main characteristics of a scrapbook [19], [20] $\&$ [21]. The materials are presented in the form of visual images accompanied by simple descriptions along with the audio to facilitate slow learners or special needs students in inclusive classes who may have difficulty understanding long sentences. Besides that, there are also explanatory videos about organs and digestive processes in the human body. This follows the principles of representation in the UDL, which provides supporting facilities to deepen the meaning in various ways.

The UDL principle also facilitates action and expression as an effort to support strategic ways of learning. Moreover, it provides opportunities for students to demonstrate their understanding in various forms, such as through tests, papers, art, multimedia presentations, and digital recordings [22]. At the end of each sub-topics, cognitive difficulties are available as an exercise for students to remember the materials they have learned. Further, reinforcing activities are also given, such as matching pictures of organs with their names and functions and making practicum recordings. 
The students were excited to present their work due to these various activities instead of item drilling, which has become a scourge in online learning.

The experimental class' science learning outcomes were enhanced as the Science Digital Scrapbook supplies diverse ways of engagement to assist effective learning and to consider how to involve students in stimulating their interest and motivation through collaborative learning, games, and simulations, real and virtual [16],[23]. This principle is facilitated through the observation of practicum simulation activity before carrying out independent experiments so that students are involved in reporting the practicum process. Each student's practicum results collaborated with their friends. Other than that, the students also accessed the content on their own, which resulted in a better mastery of content compared to when they were directed by the teacher.

A study proved that scrapbooks can improve student learning outcomes and are superior to other media[24]. Similarly, this study's findings unveiled that there was a difference between the students learning using the UDLbased scrapbook and those taught using conventional printed books [25], [26], [27]. A concrete learning experience guarantees learners' thinking skills development [28]. Scrapbook is an audio-visual medium comprising moving images and sound effects [29]. It made activities more interesting in the experimental class [30] and stimulated the learners to answer questions and do assignments following those contained in the media [31].

The UDL-based Science Digital Scrapbooks also enabled students to have more time in learning than studying could be carried out anywhere and anytime [32]. This learning activity contribute to the varied learning resources. Furthermore, the technological developments in the industrial revolution era have changed people's lives as every individual is required to follow technological developments [33].

\section{CONCLUSION}

The Science Digital Scrapbook based on UDL improved student learning outcomes compared to the control group. Thus, it is concluded that the UDL-based Science Digital Scrapbooks are beneficial in improving students' learning outcomes.

\section{AUTHORS' CONTRIBUTIONS}

IUW developed the theoretical formalism, performed the analytic calculations, contributed to the final version of the manuscript; SS and NJ implemented the research.

\section{ACKNOWLEDGMENTS}

The contract number of fund research of Universitas Negeri Semarang was SP DIPA-023.17.2.677507/2020.

\section{REFERENCES}

[1] O. Chandasiri, "The COVID-19: impact on education." Journal of Asian and African Social Science and Humanities 6.2, 2020, 38-42.

[2] Kahfi, Tantangan Dan Harapan Pembelajaran Jarak Jauh Di Masa Pandemi Covid 19, Dirasah: Jurnal Pemikiran dan Pendidikan Dasar Islam, 3(02), 2020, 137-154.

[3] M. Mutiani, \& M. Faisal, Urgency of the 21st century skills and social capital in social studies, The Innovation of Social Studies Journal, 1(1), 2019, 1-11.

[4] X. Zhu, \& J. Liu, Education in and after Covid-19: Immediate responses and long-term visions, Postdigital Science and Education, 2(3), 2020, 695-699.

[5] S. Farhana, I. Magdalena, \& A. Safitri, Strategi Guru dalam Meningkatkan Kualitas Mengajar di Masa Pandemi COVID-19, Cerdika: Jurnal Ilmiah Indonesia, 1(3), 2021, 313-320.

[6] N. A. Handayani, \& J. Jumadi, Analisis Pembelajaran IPA Secara Daring pada Masa Pandemi Covid-19. Jurnal Pendidikan Sains Indonesia, 9(2), 2021, 217-233.

[7] I. Zutiasari, Development of Digital Sway Teaching Materials for Online Learning in the COVID-19 Pandemic Era. KnE Social Sciences, 2021, 200209.

[8] M. F. Tamara, V. Tulenan, \& S. D. Paturusi, Aplikasi Pembelajaran Interaktif Sistem Pencernaan Manusia Untuk Siswa Sekolah Dasar, Jurnal Teknik Informatika, 14(3), 2019, 377-386.

[9] I. U. Wusqo, M. Taufiq, \& R. Handayani, Pengembangan Asesmen Alternatif Praktikum Kimia Dasar Ii Melalui Chemistry Fair Project (Cfp) Berbasis Konservasi Dengan Memanfaatkan Daily Chemical, Jurnal Penelitian Pendidikan Indonesia, 33(2), 2016, 145-154.

[10] I. U. Wusqo, S. D. Pamelasari, M. Khusniati, A.Yanitama, \& F. R. Pratidina, The development and validation of science digital scrapbook in a universal design for learning environment, In Journal of Physics: Conference Series (Vol. 1918, No. 5, p. 052090), IOP Publishing, 2021.

[11] D. Sugianto, Modul Virtual: Multimedia Flipbook Dasar Teknik Digital, Jurnal INVOTEC, 9 (2): 2013, 101-116.

[12] A. S. Pamungkas, \& S. B. Sartika, The Role of Primary School Teacher's on Teaching and Learning from Home with WhatsApp Group, Jurnal Ilmiah Sekolah Dasar, 5(1), 2021.

[13] A. Malyana, Pelaksanaan Pembelajaran Daring dan Luring Dengan Metode Bimbingan Berkelanjutan Pada Guru Sekolah Dasar Di Teluk Betung Utara Bandar Lampung, Jurnal Ilmiah Pendidikan Dasar Indonesia, 2(1), 2020, 67-76.

[14] I. U. Wusqo, M. Khusniati, S. D. Pamelasari, A Laksono, \& D. Wulandari, The Effectiveness of Digital Science Scrapbook on Students' Science Visual Literacy, Jurnal Pendidikan IPA Indonesia, 10(1), 2021, 121-126. 
[15] P. King-Sears, Introduction to" Learning Disability" Quarterly Special Series on Universal Design for Learning: Part One of Two, Learning Disability Quarterly, 37(2), 2014, 68-70.

[16] R. S. Wahyuningtyas, The Effectiveness of Learning with Z-Generation Video on Skeletal System Materials Towards Critical Thinking of Senior High School Students, In 2nd Annual Conference on blended learning, educational technology and Innovation (ACBLETI 2020) (pp. 334-339), Atlantis Press, 2021.

[17] F. Katili, Application Of Discovery Learning Model To Improve Results Of Science Learning In Class V Students Of SDN I Tataaran, In International Conference Primary Education Research Pivotal Literature and Research UNNES 2018 (IC PEOPLE UNNES 2018) (pp. 92-94). Atlantis Press, 2019.

[18] L. A. Clyde, Digital scrapbooking. Teacher Librarian, 33(2), 2005, 53-56.

[19] K. D. Good, From scrapbook to Facebook: A history of personal media assemblage and archives, New media \& society, 15(4), 2013, 557573.

[20] K. Lenters, Telling "a story of somebody" through digital scrapbooking: A fourth grade multiliteracies project takes an affective turn, Literacy Research and Instruction, 55(3), 2016, 262-283.

[21] M. T. Marino, C. M. Gotch, M. Israel, E. Vasquez III, J. D. Basham, \& K. Becht, UDL in the middle school science classroom: Can video games and alternative text heighten engagement and learning for students with learning disabilities?, Learning Disability Quarterly, 37(2), 2020, 87-99.

[22] G. Rappolt-Schlichtmann, S. G. Daley, Lim, S., Lapinski, S., Robinson, K. H., \& Johnson, M. (2013). Universal Design for Learning and elementary school science: Exploring the efficacy, use, and perceptions of a web-based science notebook., Journal of educational psychology, 105(4), 1210.

[23] E. Putri, L. F. Yeni, \& T. Titin, The Effectiveness of Scrapbook on Learning Outcomes of 10th Grade Students Public Senior High School 6 Pontianak on Protista Subject, IJIS Edu: Indonesian Journal of Integrated Science Education, 3(2), 2021, 125-132.

[24] I. P. Adipati, Digital Scrapbook Learning On Environmental Pollution By Using Canva To Construct Students'scientific Literacy And Communication Skill (Doctoral dissertation, Universitas Pendidikan Indonesia, 2019.

[25] I. Veronica, R. W. Pusari, \& M. Y. Setiawardana, Pengembangan media scrapbook pada pembelajaran IPA, Jurnal Imiah Pendidikan dan Pembelajaran, 2(3), 2018, 258-266.

[26] R. E. Yuniar, N. Suprapto, \& H. Mubarok, Triggering Students' Scientific Literacy through Static Fluid Scrapbook, In Journal of Physics: Conference Series (Vol. 1491, No. 1, p. 012057 , IOP Publishing, 2020

[27] N. M. Susanti, I. N. Suardana,, \& M. Suwenten, Penerapan Model Pembelajaran Guided Inquiry Untuk Meningkatkan Aktivitas Dan Hasil Belajar Kimia Di Kelas X MIPA, Jurnal Pendidikan Kimia Indonesia, 1(2), 2017, 53-59.

[28] A. F. Amalina, Pengembangan Media Scrapbook Dengan Penerapan Pendekatan Kontekstual Pada Muatan Pelajaran Ipa Kelas V Sekolah Dasar, Jurnal of admiration, 1(5), 2020, 468-478.

[29] I. K. Werdhiana, Wahyono, U., \& Miftah, M. (2020). Implementasi Perangkat Pembelajaran
Audio Visual IPA Berbasis Energi Surya untuk Meningkatkan Motivasi dan Minat Belajar Siswa SMP di Daerah Tertinggal, JPFT (Jurnal Pendidikan Fisika Tadulako Online), 8(1).

[30] D. M. A. Sujana, I. G. N. Japa, \& L. P. Y. Yasa, Meningkatnya Hasil Belajar IPA Siswa Melalui Model Problem Based Learning Berbantuan Media Audio Visual, Jurnal Imiah Pendidikan dan Pembelajaran, 5(2), 2021.

[31] Y. Fitriyani, I. Fauzi, \& M. Z. Sari, Motivasi belajar mahasiswa pada pembelajaran daring selama pandemik covid-19, Jurnal Kependidikan: Jurnal Hasil Penelitian dan Kajian Kepustakaan di Bidang Pendidikan, Pengajaran dan Pembelajaran, 6(2), 2020, 165-175.

[32] A. Szymkowiak., B. Melović, M. Dabić, K. Jeganathan, \& G. S. Kundi, Information technology and Gen Z: The role of teachers, the internet, and technology in the education of young people, Technology in Society, 65, 2021, 101565. 